\title{
AN INTRODUCTION TO THE LETTERS OF ISAIAH MOTEKA: THE CORRESPONDENCE OF A TWENTIETH-CENTURY SOUTH AFRICAN ZIONIST MINISTER
}

\author{
Joel Cabrita
}

The National Archives in Pretoria contain over sixty letters written by Isaiah Moteka, a Zionist church minister, between 1935 and 1965, addressed both to government officials and to Moteka's fellow clergymen. The thousands of Zionist churches constitute one of the largest Christian movements in black society of twentieth-century South Africa. But Zionists did not merely write letters to local recipients, nor was their form of Christianity simply a regional phenomenon. Brought to the country by missionaries from the Christian Catholic Apostolic Church in Zion, Illinois, South African Zionism continued to possess a keenly cosmopolitan imagination long after the missionaries' departure. Their letters delineated the contours of the global Zion fellowship: a multiracial epistolary diaspora linking South Africa to the small Midwestern town of Zion, Illinois.

The large literature on Zionist Christianity usually depicts Zionists as more interested in ritual than in literate expression. Much scholarly attention focuses on Zionists' healing therapies (Comaroff 1985), their religious dress (Kiernan 1991), and their pilgrimages (Muller 2011). By the 1960s - the era of decolonization - anthropologists and scholars of religion were claiming Zionist rituals as evidence of the resilience of oral indigenous religion to the Westernized, text-focused Christianity of missionaries (Oosthuizen 1967). Scholars acknowledged the importance of language in Zionist ritual, particularly hymnal singing and the spoken benedictions uttered upon curative substances (Kiernan 1978; 1990). But their emphasis lay with the spoken, oral aspect of language, rather than with Zionists' interest in texts and paperwork. Moteka's letters offer a different picture of Zionists' engagement with print capital. They demonstrate how minimally educated black Zionists in fact eagerly participated in textual production, often drawing upon scribes to do so (Barber 2006).

In particular, this article demonstrates how texts mediated Zionists' cosmopolitan imagination. A growing literature refutes the older depiction of South Africa as isolated both from the history of the African continent and from wider global histories (Hofmeyr 2004; 2013). Much of this scholarship underscores transatlantic networks, characterizing African relations with North America as a worldwide black diaspora (Campbell 1998; Vinson 2012). Moteka's letters, by contrast, reveal an epistolary network marked by its racial inclusivity, connecting both whites and blacks. It is true that letters are frequently linked to the

JOEL CABRITA is University Lecturer in World Christianities at the University of Cambridge. Her monograph on South African Christianity and its print culture is published by the International African Institute and Cambridge University Press as Text and Authority in the South African Nazaretha Church (2014). Her current research project is on the transatlantic history of South African Zionism in the twentieth century. Email: jmc67@cam.ac.uk

(C) International African Institute 2014 
emergence of an African private sphere in the colonial and postcolonial period, 'assigned a special, central role in the imagination of new modes of privacy and personhood' (Barber 2007: 177). But recent studies highlight the work letters accomplished in summoning up new publics. Mission station elites wrote letters addressing each other as a community of enlightened moderns (Khumalo 2006); letters could also connect rural families with male relatives working in the mines, creating literary circuits that traversed the urban-rural divide (Breckenridge 2000). Moteka, though, was determined to write into existence a global network. In order to do this, he lent upon the literary traditions of evangelical Protestantism. Indeed, Protestantism's epistolary practices have long been used as techniques for regional nodes of believers to constitute themselves into trans-regional fellowships (O’Brien 1986).

But Moteka's letters also mediated his local preoccupations. In particular, his correspondence reflects his efforts to advantageously position his church within the South African state. There is a long tradition of treating popular Christian movements such as Zionism as bastions of resistance to white rule (Comaroff 1985; Fernandez 1978: 216). Other scholars thought differently, identifying Zionist healing rituals as affirmations of the status quo (Schoffeleers 1991). Moteka's correspondence reveals that, rather than falling into these polarized categories, he and other Zionists related to the state through persuasive literary tactics that strove to alter officialdom's perceptions. And it was partly to convince officials of his church's respect for local authority that Moteka's letters adopted the bureaucratic idioms of governmental paperwork. But at the same time, as we shall shortly see, the letters strained against fixed territorial borders. In doing so, these documents intimated the subordination of local politicians to the universal rule of Jesus Christ, a figure Moteka identified in his correspondence as 'the Prince of Peace'.

\section{SOUTH AFRICAN ZIONISM}

The founder of the worldwide Zion church was an Australian-Scot named John Alexander Dowie; in 1896, he inaugurated the Christian Catholic Church in Chicago, USA. Dowie's church was characterized by the period's typically Protestant interest in the 'Higher Life', the conviction that conversion was the beginning of the Christian life, not the end, and that it must be followed by a radical purification of the self (Blumhofer 1993). In particular, faith healing - or divine healing, as nineteenth-century practitioners dubbed their pursuit of health through prayer - was viewed by Dowie as the quintessential activity of sanctified people. In the 1890s, Dowie established a church periodical, Leaves of Healing, which was comprised of converts' testimonies to their healing, expressed largely in the form of grateful letters to Dowie. To showcase this correspondence, the periodical skilfully adopted the techniques of popular broadsheets, including eye-grabbing headlines, compelling stories and dramatic photographs. In 1900, Dowie moved his several thousand followers to a small settlement that he named Zion, north of Chicago on the shores of Lake Michigan. Biblical models for holy living were followed: doctors and medicine were forbidden, as was the consumption of pork, alcohol and tobacco, inspired by Dowie's reading of the biblical Book of Leviticus; even streets were named after characters from the 
Old Testament. Bolstered by his followers' belief in his divinely ordained standing, Dowie exercised autocratic rule over the community. In 1901, Dowie claimed that he was the reincarnation of the Hebrew prophet Elijah, and, in 1904, proclaimed himself the 'First Apostle', inserting 'Apostolic' into the church's name (Cook 1996: 57, 171-2).

Despite their location in a tiny Midwestern town, the inhabitants of Zion depicted their faith as a global movement. In part, this meant styling Zion-defined both literally as the actual town as well as more loosely as the fellowship of the faithful - as a home for the world's racial families. Post-bellum United States vigorously debated the standing and relation of different races. Dowie sympathized with the monogenists, who argued that the Genesis creation account of a single human race could be understood literally (Kidd 2006: 128). In 1901, Dowie asserted: 'White man, black man, yellow man, red man, brown man, we all have the same father.' And in the context of the period's debate about the rights due to African-Americans, Dowie proclaimed that 'in Zion ... black and white were blended'. ${ }^{2}$ Dowie's vision was of Zion as a harmonious global family and as a capacious home for the world's races. In this spirit, in the late 1890s Dowie sent evangelists to Canada (Opp 2005: 92-5). In 1901, a Chicago convert, Wilbur Glenn Voliva, planted the Australian church (Cook 1996: 160). Dowie's 'Around the World Visitation' of 1904 took him to New Zealand, Australia, France, Switzerland and Great Britain (ibid.: 157). Where Dowie could not go, Leaves of Healing-described by him as a 'Little White Dove' - carried divine healing. By 1903, Dowie boasted of 100,000 members across the world. ${ }^{3}$ This was taken as evidence of Zion's cosmopolitanism: '[Its] Catholicity or Universality ... means it counts among those in affiliation with it people of every land and nation, of all races and tongues.' ${ }^{4}$

Circulated by Zion's mobile print culture, Dowie's teachings found great success in South Africa. By 1897, Leaves' testimonies to faith healing were sparking interest among white British settlers and Dutch burghers. ${ }^{5}$ In 1904, Dowie sent two missionaries to South Africa, Overseer Daniel Bryant and his wife, Elder Emma, who, as well as working among white Zionists, also supervised a thriving ministry among blacks of the Transvaal and Orange Free State. The Bryants collaborated with Edgar Mahon, a former Salvation Army officer from the farmlands around Harrismith, and Pieter Le Roux, an ex-Dutch Reformed minister working among Zulu congregations in Wakkerstroom, Transvaal. In conjunction with their African under-workers - men such as Daniel Nkonyane, Fred Luthuli and Muneli Ngobese - Bryant, Mahon and Le Roux held revival meetings in Wakkerstroom, Harrismith, Volksrust and the small neighbouring kingdom of Basutoland. These events were remarkably popular with African audiences. ${ }^{6}$ Mahon reported that 'about six hundred professed to find salvation, and I saw over twenty thousand people at our meetings'. ${ }^{7}$ Le Roux commented on

\footnotetext{
${ }^{1}$ Leaves of Healing, March 1901.

${ }^{2}$ Zion Banner, 1 September 1905.

${ }^{3}$ Mercury Cape Town, 10 November 1903.

${ }^{4}$ Leaves of Healing, 28 January 1899.

${ }^{5}$ Ibid., 20 October 1899.

${ }^{6}$ Ibid., 16 July 1904.

${ }^{7}$ Ibid., 14 October 1905.
} 
the particular attraction of healing, noting that 'as soon as [Africans] see divine healing taught in the Bible they unquestioningly accept it' ${ }^{8}$ Bryant similarly reported its vast popularity: 'we asked all who had been healed through faith in Jesus Christ to lift the hand. Like a flash the hands went up.'

Zion's literary culture, and in particular Leaves of Healing, fostered communion between Zion in America and Zion in South Africa. Dowie commanded Bryant upon his arrival in Johannesburg to 'lay much stress on subscription to Leaves ... this brings them into close touch both with myself, and Headquarters, and the wide scope of Zion throughout the world.' 9 Reading Leaves, then, South African converts viewed their testimonies alongside those letters contributed by believers throughout the world. For example, in April 1900 Leaves featured items by fellow-believers in South Africa, Chicago, Indiana, Egypt, Kansas and Canada. The magazine's editors emphasized the global scope of their readership, regularly enumerating the issues sent to locations as diverse as Canada, India, China and Palestine. Another device was to list the countries that submitted correspondence, lauding the 'letters received from England, Scotland, Ireland, France, Germany, China, Japan, Natal, Cape Colony, ZAR [Zuid-Afrikaansche Republiek or South African Republic], OFS [Orange Free State], Palestine, Madras, India, British Guinea, Australia, New Zealand and Hawaii'. ${ }^{10}$ The Zion Prayer Clock was a drawing of a clock that featured regularly in Leaves and displayed the different times in Zion's worldwide gatherings, emphasizing the church's common global prayer. ${ }^{11}$ Furthermore, Dowie also frequently used popular nineteenth-century technologies such as the telegraph and marconigraph in order to send and receive cables to and from worldwide Zionists.

But within a few years, Dowie's Zion empire had disintegrated, both in its American headquarters and abroad. His financial mismanagement led the sick, elderly Dowie to be removed by his followers in 1906; leadership was assumed by Voliva, his Australian deputy (Cook 1996: 195-6). Almost immediately, the church fragmented into five factions, each led by an individual claiming to be Dowie's successor. One of the groups that rejected Voliva's legitimacy summoned Bryant from South Africa to lead them (ibid.: 218). Schism in Zion, Illinois led to division in Zion, South Africa. Edgar Mahon in the Harrismith area now affiliated himself with Daniel Bryant's rival church, severing himself from old Zion. In the meantime, many white Zionists in South Africa turned to the new teachings of the Pentecostal Apostolic Faith Mission (AFM), an extension of the Azusa Street movement of Los Angeles that emphasized speaking in tongues. In 1908, Le Roux was ordained within the AFM, taking most of his black Zionist congregation with him. ${ }^{12}$

Soon, however, large numbers of Africans returned to Zion. Before long, the new Pentecostal AFM had incorporated racial segregation into its worship. Zion, by contrast, still offered Africans membership of a multiracial global fellowship.

\footnotetext{
${ }^{8}$ Ibid., 8 October 1904.

${ }^{9}$ Christ Community Church Archives, John Alexander Dowie to Daniel Bryant, 5 November 1903: 10.

${ }^{10}$ Leaves of Healing, 15 April 1901.

${ }^{11}$ Ibid., May 1903.

${ }^{12}$ The Comforter, October 1913.
} 
Their overseas alliances gave Africans leverage to resist the efforts of former white Zionists such as Le Roux to impose religious 'orthodoxy' on them. Through citing their affiliation to Zion, USA, black Zionists paradoxically staked out religious independence at home (Sundkler 1976: 40, 51). And in the context of the multiple leadership disputes in Illinois, complex connections came to rope together various denominations in the USA with rapidly sprouting counterparts in South Africa. In 1911, Elias Mahlangu, one of the early Wakkerstroom Zionists, broke away from the AFM and started the Zion Apostolic Church, receiving encouragement from Voliva (ibid: 60). In the same year, Daniel Nkonyane, another key Wakkerstroom figure, formed his own branch of the Christian Catholic Apostolic Church in Zion. In doing so, he was patronized by one of Voliva's competitors in Zion, Illinois, a man named Royall (ibid.: 58). Paul Mabilitsa, who had preached in Basutoland with Mahon in the early days, also formed his own rival Christian Catholic Apostolic Church in Zion, with its headquarters in Johannesburg, and worked closely with yet another Illinois claimant (ibid.: 58). These early black Zion congregations were highly fissiparous: internal disputes led many members to break away to form their own rival groups. By 1932, the AFM counted more than 400 Zionist churches (Anderson 1992: 30; Sundkler 1948: 354). Local impulses coexisted alongside transatlantic alliances. The largest Zionist organization of the twentieth century was the Zion Christian Church, now possessing about 6 million members. Although originally linked to Zion, Illinois, ZCC church leaders have long obscured their American origins, far preferring to depict their powerful institution as an indigenous phenomenon (Anderson 1992: 29).

South African officials reacted with alarm to this proliferation of black Zion congregations. The Native Affairs Department (NAD) fretted about African churches independent of European supervision, describing them through idioms of uncontrollable mutation (Claassen 1995: 25). At an early date, Zionism had ceased to have white members in South Africa; for this reason, the continued involvement of whites in the USA was obscured from official eyes. The 'Bulhoek Massacre' of 1921, when followers of the Eastern Cape prophet Enoch Mgijima violently clashed with police, confirmed official perceptions of independent black churches as politically troublesome. ${ }^{13}$ In the incident's aftermath, the government announced that 'separatist' churches - those that appeared independent of white supervision - would have to apply for the government's recognition. After 1926, without recognition, churches were unable to gain sites for religious buildings and school premises; black ministers were legally barred from acting as marriage officers, forbidden to buy sacramental wine, and ineligible for concessions for railway travel.

However, in addition to overt repression, the state was also determined to gain information regarding the inner workings of these organizations. They hoped that this knowledge would empower them to forestall impending unrest (Cabrita 2014: 302). To this end, the government publicized criteria of 'standing and stability', which they claimed, if met, would render African churches eligible for recognition. The government instituted an application procedure whereby interested clergymen could write to the Secretary for Native Affairs (SNA) requesting

\footnotetext{
${ }^{13}$ Report of the Native Churches Commission, 7-17.
} 
recognition. ${ }^{14}$ Crucially, applicants were required to submit detailed information on the size, location and history of their congregations, as well as to provide documentary evidence including maps, baptismal registers and ordination certificates. Yet in the forty years that these applications were received by the NAD - the process was discontinued in 1963 - only eight African churches were recognized; these were all organizations that had long-established links with white missionary societies (Sundkler 1948: 354-74). Much of the rationale of the procedure lay not in applicants' ability to successfully clear its hurdles, but rather in its ability to extract valuable information for the benefit of the state from black clergymen.

Despite the odds, Zionists eagerly seized upon this slight hope of improved standing. Between 1926 and 1963, over 1,000 clergymen wrote letters requesting recognition from the NAD (Houghton 1956: 72). In seeking to persuade officials of their quiescence, Zionists framed their requests in the formal register of bureaucratic paperwork. This was a rhetoric with which all Africans were intimately familiar via the documentary regime of pass book, permit and tax receipt. But Zionists' letters also used other types of language. They employed literary devices that asserted their position not only within the regional bureaucracy of the South African state, but within the worldwide Zion movement. On the one hand, such internationalism reassured a wary state that Zionists were part of an established, white-led organization. But the literary cosmopolitanism of local Zionist intellectuals such as Isaiah Moteka could also be perceived as deeply subversive by a state seeking to contain Africans through the locally determined bureaucratic disciplines of the recognition procedure. Moteka's letters illuminate the process whereby one mode of letter-writing - the legalistic and the bureaucratic-coincided with the more expansive register of the epistolary practices of the Zion church.

\section{ISAIAH MOTEKA: EPISTOLARY COSMOPOLITAN}

Born in about 1886, Isaiah Moteka was baptized during the early Zion revival in South Africa; later in life, he claimed he 'joined the church in 1905 in the days of the First Apostle (John Alexander)'. ${ }^{15}$ Moteka was educated by Paris Evangelical missionaries at a station called Cana in Basutoland and gained Standard 4, his highest educational qualification. ${ }^{16}$ Nothing further is recorded in the archives about his next thirty years. By 1934, Moteka had established himself as a church minister, and founded a branch of the Christian Catholic Apostolic Church in Zion in his small hometown of Bethlehem, Orange Free State. Moteka's church grew steadily: ten years later, there were 640 members, including 334 in the Free State, 267 in the Cape and forty in the Transvaal. ${ }^{17}$ Moteka was ambitious and self-improving: in the 1940s he enrolled on an English correspondence course. ${ }^{18}$ Indeed, all his letters held in the National Archives are in English (even those written to black Zionist colleagues), perhaps reflecting his aspiration to

\footnotetext{
${ }^{14}$ Ibid.

${ }^{15} \mathrm{SAB}$, NTS 1430 File No. 23/214, Volume III, Moteka to Wilkinson, July 1952.

${ }^{16} \mathrm{Ibid}$, Moteka to SNA, 16 July 1945.

${ }^{17} \mathrm{Ibid}$.

${ }^{18}$ Ibid.
} 
cosmopolitan modernity. But Moteka was equally at ease in his hometown. According to local police, Moteka was a prominent, respected figure; he was 'well-known in Bethlehem... nothing detrimental [is] known against his character'. 19

Moteka's thirty-year clerical career was undergirded by his ambition to achieve government recognition. As every black minister would have agreed, there were practical reasons for desiring this. Without recognition, Moteka's church was forbidden to erect buildings for worshippers' use. Nor could Moteka perform the proper functions of a clergyman: he was unable to purchase communion wine, lamenting he was 'obliged to use ginger beer mixed with a juice from raisins'. ${ }^{20}$ A hint of more serious harassment is given in his 1942 letter to the SNA, which requested that 'treatment meted out to the Members of this Church by the Police should be less serious, more moderate'. ${ }^{21}$ As for many Zionists, letterwriting became Moteka's preferred method of convincing officials of the state-including the SNA, the head of the NAD (later the Bantu Affairs and Administration Department [BAD]), as well as regional magistrates and native commissioners - that his organization deserved recognition. Moteka's letters were mainly written in his dense, slanting hand, which remained virtually unchanged over three decades, although several were typewritten. Judging from the occasionally different hand, a small number were written by a scribe, perhaps a congregation member lending their clerical services. ${ }^{22}$ There are several unexplained interruptions in his correspondence: among other gaps, there is no archival record of letters exchanged during the periods 1937-40, 1945-49 and 1961-65 - possibly attributable to the state's irregular archiving practices.

Moteka's letters sought to reassure officials that his organization respected state authority. His writings positioned the church as transparent to scrutiny, supplying readers with minute details of ecclesial organization, including the number of members belonging to congregations, ministers' names, addresses and educational qualifications, and even a hand-drawn map sketching the rooms used by his congregation for religious services. Moteka's letters also explicitly asserted Zionists' willingness to submit to local administrators. This was a more general pattern of such letters. Minister Nteo of the Ethiopian Catholic Church in Zion wrote to NAD officials stating that he was 'our government's servant... I will obey our Government until my last day, and I will preach in our church also to my people to obey our Government, and pray for you our Government. ${ }^{23}$ In similar fashion, Moteka's letters quoted biblical texts referencing Christians' duty to respect the nation's authorities. A 1949 letter to the SNA stated his 'desire is to fulfil the Government's law together with God's. Romans 13.'24 The divinely ordained role of the church was to bolster the country's leaders: 'I hate to be disobedient to the Government's law. I want the Government to trust me as

\footnotetext{
${ }^{19}$ Ibid., Office of the District Commandant to Magistrate Bethlehem, 8 March 1943.

${ }^{20}$ Ibid., Moteka to SNA, 22 September 1952.

${ }^{21} \mathrm{Ibid}$., Volume II, Moteka to Unknown, April 1942.

${ }^{22}$ Ibid., Volume III, Moteka to Wilkinson, July 1952.

${ }^{23}$ SAB, NTS 1420 File No. 2/214-5/214, Nteo to SNA, 29 July 1955.

${ }^{24}$ SAB, NTS 1430 File No. 23/214, Volume III, Moteka to SNA, 12 January 1949.
} 
ministers as the assistants of the Government, to teach and to lead the nation to the right.'25

But Moteka's letters also pointed to affiliations that ran counter to these local obligations. American Zionists had remained eager to forge links with their black constituency in South Africa well into the middle of the twentieth century. As in an earlier period, claiming ownership of African congregations enhanced even fairly obscure figures' legitimacy as domestic leaders in Zion, Illinois. One such individual was Edwin H. Snelling, a Zion wallpaper-maker. ${ }^{26}$ Formerly one of Dowie's inside circle, after the prophet's death Snelling and his wife, Mary, started a breakaway church. Using a printing press installed in their home, the Snellings printed their own issues of Leaves, sending these and ordination certificates to black clergy in South Africa. In addition to enhancing Snelling's own authority amid the contested milieu of Zion, Illinois, printing became a profitable business, as Snelling charged for his magazines and certificates. ${ }^{27}$ In the early 1930s, Moteka wrote to Snelling requesting doctrinal instruction, and proceeded to 'study ministry through correspondence for five years' under Snelling. ${ }^{28}$ In 1938, presumably upon successfully completing the course, Snelling ordained Moteka as the South African representative of the worldwide Zion church.

By invoking his connection to Snelling, Moteka hoped to persuade officials that his church belonged to a worldwide network of Zionist Christians - and, crucially, one headed by whites. No doubt prompted by Moteka, Snelling wrote to the NAD in 1940, confirming that he had authorized Moteka as his deputy. ${ }^{29}$ But Moteka also wrote his own letters informing sceptical officials of his standing as a 'representative man' of Zion, Illinois. ${ }^{30}$ One condition of government recognition was an applicant's ability to demonstrate a lengthy church history, evidence of its 'stability'. By citing his affiliation to Snelling, Moteka was able to argue that, rather than dating to merely 1934, his small Bethlehem congregation was founded in 1896, the year Dowie inaugurated the church in Chicago. As he noted to the SNA in 1952: 'this is an old church'. ${ }^{31}$ And in underscoring his links to Illinois, Moteka could also argue that his was no mere local sect, but part of a far larger global church. In reply to the Bethlehem magistrate's letter stating that his church was not recognized, Moteka expressed his astonishment: 'Now my Worship, I am surprised in this matter, because this church is known throughout the world.' 32

It was through juxtaposing local and global frames of reference that Moteka's letters conveyed this sense of cosmopolitan belonging. For example, weaving references to other texts into his letters meant that Moteka could position his own very particular world within much larger stories. He frequently used biblical aphorisms or stories to link the church's predicament to that of the wider, historic Christian people. In a 1943 letter addressed to the SNA, Moteka cited the

\footnotetext{
${ }^{25}$ Ibid., Volume III, Moteka to SNA, 12 January 1949.

${ }^{26}$ Interview with Grant and Barbara Sisson, Zion, Illinois, 20 July 2012.

${ }^{27}$ Ibid.

${ }^{28}$ SAB, NTS 1430 File No. 23/214, Volume III, Moteka to SNA, 16 July 1945.

${ }^{29}$ Ibid., Volume II, Snelling to SNA, 25 May 1940.

${ }^{30}$ Ibid., Moteka to SNA, 14 January 1937.

${ }^{31}$ Ibid., Volume III, Moteka to SNA, 22 September 1952.

${ }^{32}$ Ibid., Volume I, Moteka to Magistrate Bethlehem, 26 July 1935.
} 


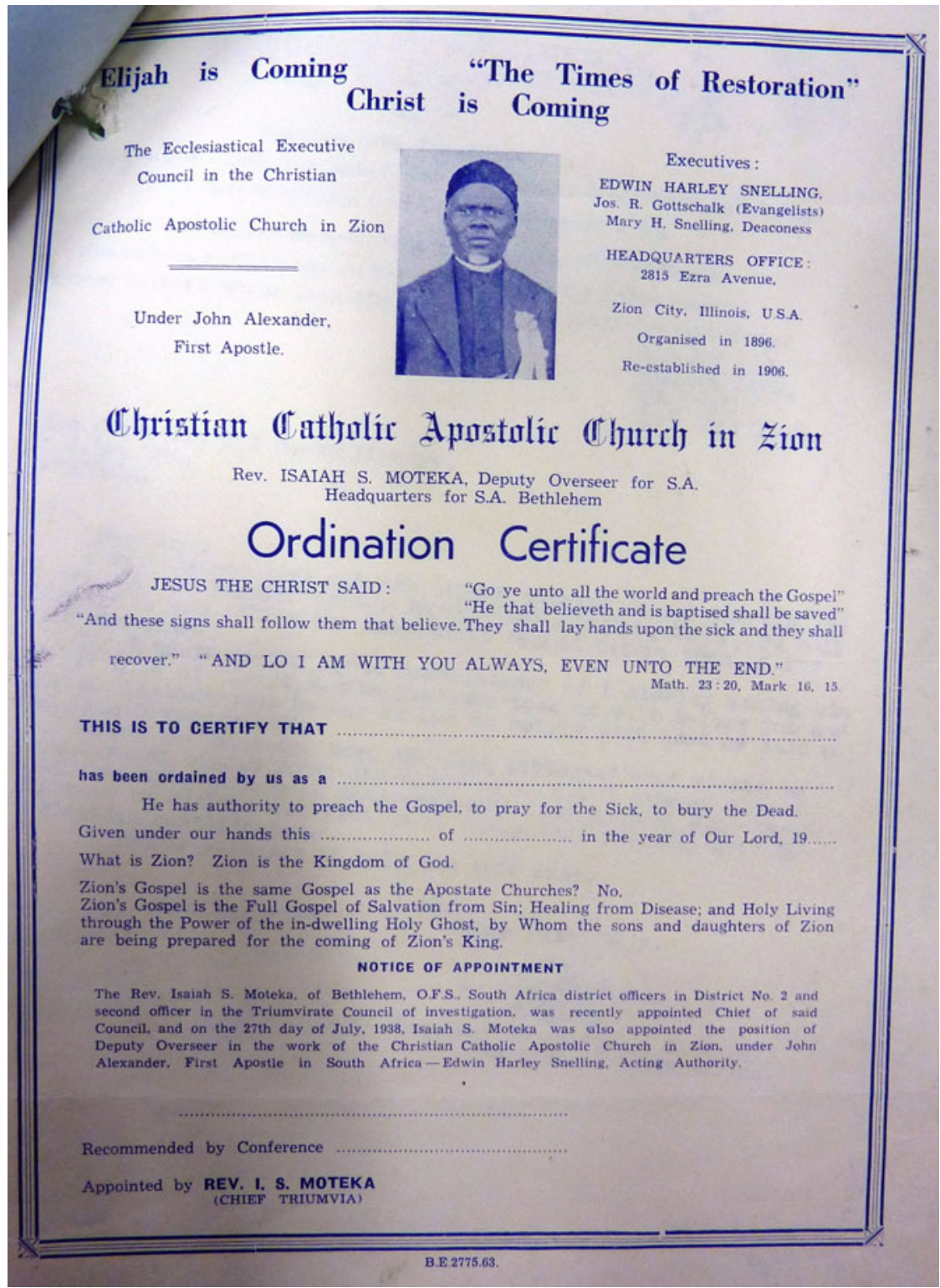

FIGURE 1 Edwin Snelling's ordination certificate for Isaiah Moteka (reproduced with the permission of the National Archives and Record Service of South Africa)

apocalyptic Book of Revelation's lament of the burning of Babylon in order to suggest the trials suffered by Zionists in the Orange Free State, South Africa. This reference also conveyed his hope that the same God who ushered in the reign of 
Christ in Revelations would deliver the small Bethlehem gathering. ${ }^{33}$ Similar comparative strategies underpinned Moteka's occasional mention of Leaves of Healing. In a letter of 1935 he provided a detailed reference to the exact volume and issue of the periodical in which he was listed as an early convert. ${ }^{34} \mathrm{His}$ goal was to flag up his inscription within the annals of the global movement. In the same spirit, Moteka's epistolary prose demonstrates continual slippage between the local and the global, invoking in the same breath loyalty to Pretoria, South Africa and to Zion, USA. And while his home-made letterhead identified him in narrowly local terms - a resident of 'House No. 222, Native Location, Bethlehem' - he also signed off those same letters with assertions of his national stature: 'Isaiah Moteka, Deputy Overseer Chief Triumvir in Christian Catholic Apostolic Church in Zion Throughout South Africa. ${ }^{35}$ Moreover, in signing off from his correspondence, he flamboyantly folded local nomenclature into transatlantic stature:

(Rev.) Isaiah Moteka, Under Evangelist Edwin Harley Snelling, Acting Authority in the Christian Catholic Apostolic Church in Zion under Dr. John Alexander Dowie, First Apostle of the Lord Jesus the Christ, 2815 Ezra Avenue, Zion City, Illinois, USA. ${ }^{36}$

To the same end, Moteka also cast his letters as quasi-official documents that certified his accreditation as a local worker within an international movement. Moteka made stamps identifying himself as 'Isaiah S. Moteka... Officer-inCharge, Bethlehem, O.F.S., Zion City, USA', and imprinted his letterhead with this insignia. Moteka also jealously defended his own name, alerting the SNA politely, but firmly, that he had misspelt his name ('instead of Moteka you put Moeteka'), and requesting: 'I should like you please sir to write my name always in a proper way, please. ${ }^{37} \mathrm{~A}$ stamp only performed its work if it could indisputably link Moteka's name, spelt in the correct manner, to the American church. In a mark of his recognition of the power of bureaucratic paperwork, and its attendant paraphernalia, Moteka hoped that state officials would be persuaded by the legitimating power of his self-made stamps; indeed, one letter instructed the SNA to 'examine the seal above, and find my standing'. ${ }^{38}$

Moteka's expressions of religious internationalism lent considerable ambiguity to his professions of loyalty to local authorities. For one thing, in distinction to the doctrines of the segregationist apartheid state, Moteka's letters articulated the racial fraternity typical of Zion's teachings. One of his first letters informed the SNA that 'the teaching of the Christian Catholic Apostolic Church in Zion is Peace not Hatred, not division between white people and black people, hatred comes from the Devil, but peace from God. ${ }^{39}$ A rare hint

\footnotetext{
${ }^{33} \mathrm{Ibid}$., Volume III, Moteka to SNA, 4 July 1943.

${ }^{34}$ Ibid., Volumes I and IV, Moteka to Magistrate Bethlehem, 26 July 1935.

${ }^{35}$ Ibid., Volume III, Moteka to Wilkinson, 24 July 1952.

${ }^{36}$ SAB, NTS 1428 File No. 19/214, 18 February 1935.

${ }^{37}$ SAB, NTS 1430 File No. 23/214, Volume II, Moteka to SNA, 23 April 1942.

${ }^{38}$ Ibid., Volume I, Moteka to SNA, 14 January 1937.

${ }^{39}$ Ibid., Volume I, Moteka to SNA, 17 June 1934.
} 


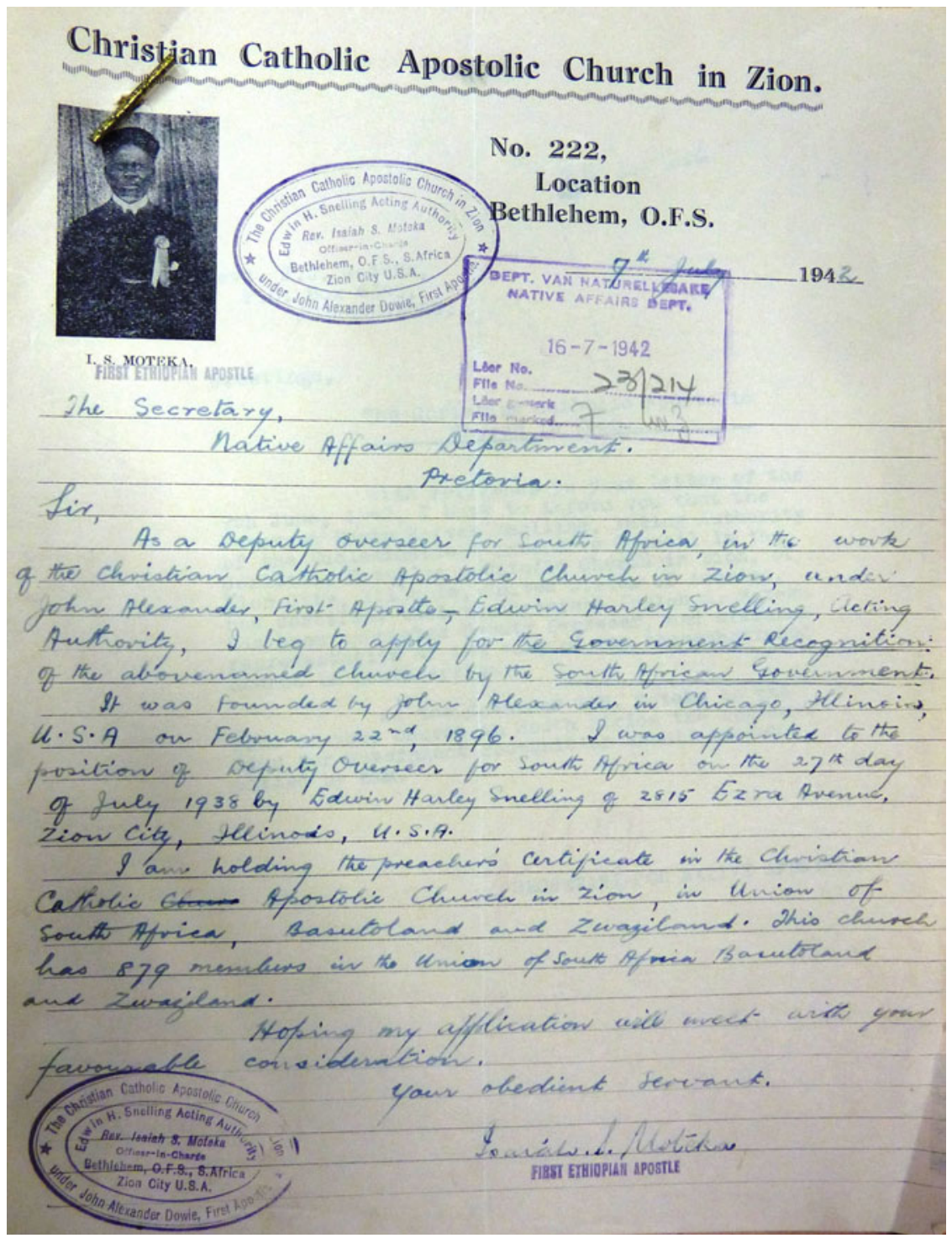

FIGURE 2 Handwritten letter with stamp, photograph and letterhead (reproduced with the permission of the National Archives and Record Service of South Africa)

of overt criticism of the state's racial policies-it divided blacks from whites, denying Africans full citizenship-is evident in Moteka's letter of 1942, in which he poignantly alludes to 'the Troubles of my Nation... it's really very far for us to have a good civilization. We can be educated, but it's in 
vain. ${ }^{40}$ And in an assertion of Zion's alternative programme, a racial cosmopolitanism inaugurated by Jesus Christ, the 'Prince of Peace', over three decades Moteka's refrain at the close of his letters was unchanging: 'Peace be still between black and white, says the Prince of Peace to the Prince of Darkness. ${ }^{31}$ Moreover, in keeping with his textual habit of intertwining multiple spheres of reference, Moteka also invoked other, more mundane, spheres in which blacks aspired to equality with whites. Echoing popular black sentiment, Moteka's letters identified the British Empire as a non-racial and egalitarian public. He named England 'our place of hope', repeatedly stating his desire to be 'under the kind Banner of our noble king of England. Amen.'42 The rivalry implicit in Moteka's expression of loyalty to this far-off authority-Zionists looked to 'the kind care hand or flag of the king George the Fifth amen'-could not have escaped the attention of officials who read Moteka's missives. Finally, Moteka's letters cast government officials as merely supporting actors in a larger biblical drama, and, in this way, subtly displaced their recipients from accustomed positions of power. His letters obliged NAD officials to usher in the Kingdom of God; in 1942, Moteka informed an official of his duty to foster 'the unity of all races ... the NAD will prevail against the power of the Devil and bring back the nations to God. ${ }^{43}$ His prose reminded officials that their privileges were derived from God, not Pretoria. In 1934, Moteka informed the SNA: 'it is written that there is not a kingdom of this world which does not come down from heaven.' ${ }^{44}$

But despite his effusive celebration of Zion's internationalism, and its corresponding racial cosmopolitanism, Moteka's letters also suggest the tensions within the worldwide Zion family. Indeed, Moteka's relationship with Zion, USA became increasingly conflicted. After Snelling's death, his congregation in Zion was taken over by one Bart M. Wilkinson. Moteka hoped for a harmonious relationship with Wilkinson, writing to him that "by the help of God I hope our work will be run very smoothly by working together in peace and harmony as it has been the case in the days of the late Snelling, acting authority'. ${ }^{45}$ But in 1956, for unknown reasons, Wilkinson posted a ministerial certificate to Joshua Nyaweni, of KwaThema, Springs, Transvaal, authorizing him as Zion's representative. Betrayed, Moteka angrily wrote to Wilkinson, implying that he was an illegitimate Zion leader. ${ }^{46}$ Wilkinson's actions remain unexplained, but the archival record reveals that he went on to appoint large numbers of competing representatives in South Africa, perhaps considering this a route to consolidating his own domestic power. Another rival to Moteka was J. S. Maduna of Ladysmith, who had similarly been recognized by Wilkinson, and who called himself 'President' in South Africa. ${ }^{47}$ In the 1940s, John Ndlovu of Germiston

\footnotetext{
${ }^{40}$ Ibid., Volume II, Moteka to unknown, 2 January 1942.

${ }^{41}$ SAB, BAO 7286, Moteka to SNA, 9 March 1957.

${ }^{42}$ SAB, NTS 1430 File No. 23/214, Volume II, Moteka to SNA, 23 April 1942.

${ }^{43}$ Ibid., Volume III, Moteka, 4 July 1943.

${ }^{44}$ Ibid., Volume I, 17 June 1934.

${ }^{45}$ Ibid., Volume III, Moteka to Wilkinson, July 1952.

${ }^{46}$ SAB, BAO 7286, Moteka to Wilkinson, 25 July 1957.

${ }^{47}$ SAB, NTS 1430 File No. 23/214, Volume II, Maduna to SNA, 9 June 1942.
} 
claimed the same title, briefly enjoying Wilkinson's patronage, ${ }^{48}$ in the $1950 \mathrm{~s}$, Minister Nyaweni was also appointed Bishop in South Africa by Wilkinson. ${ }^{49}$

Amidst this contested milieu of local rivals vying for transatlantic validation, Moteka's letters to NAD officials became instruments for undercutting his competitors. He accused rival clergymen of repudiating Zion's cosmopolitanism and instead inciting anti-European sentiment, claiming that they 'have bad teaching (hatred teaching) ... they teach the nations to hate the white people... they [formed] their own church, namely African Zion. ${ }^{50}$ In a similar spirit, Moteka's letters accused competitors of disrupting law and order: 'sometimes accidents occur at their preaching places through fights which arise'. ${ }^{1} \mathrm{His}$ missives accentuated the illegitimacy of those who claimed the right to use his church's name. Edgar Mahon was denounced as a 'thief' who had 'deceived the natives of South Africa... [and] he is not ashamed even to deceive the government. 52 Above all, Moteka's letters argued that, unlike him, his rivals enjoyed no legitimacy from Zion, Illinois, playing upon the government's dislike of independent churches that operated autonomously of white supervision. A clerical enemy of the 1940s was unmasked as a lone pretender rather than a legitimate representative of the global movement: 'As I understand it, he couldn't send overseas to get good support.' 53 In the 1950s, Moteka complained to the SNA about unsupervised 'native bishops' who had 'no white man amongst them':

I don't know where these native bishops come from ... the thing that makes them spoil the so-called Christian Catholic Apostolic Church in Zion is because there's no white man amongst them. It makes me mad, really, my Worship. ${ }^{54}$

But officials of the government remained steadfastly unpersuaded by Moteka's citation of his transatlantic legitimacy. The proliferation of African clergymen, all addressing letters to government officials, and all claiming to be bona fide deputies of the global movement, undermined Moteka's bid. In an earlier period, the SNA had on at least one occasion refused to enter into correspondence with other ministers because it was Moteka whom they believed to be certified as Snelling's deputy. ${ }^{55}$ But by the 1950 s, the greater climate of contention meant that state officials were less certain that Moteka was the legitimate representative of Zion in South Africa. In 1951, the SNA commented on the 'various Native evangelists in practically every Province of the Union [who] had laid claim to being the "Spiritual Head", the "leader", the "representative", the "general overseer" etc of the church'. Besieged by multiple conflicting certificates from the United States, each announcing that its holder was the sole representative in South Africa, the SNA professed himself 'unable to state who [was] the actual

\footnotetext{
${ }^{48}$ Ibid., Ndhlovu to SNA, 15 September 1941.

${ }^{49}$ SAB, BAO 7286, Moteka to Wilkinson, 25 July 1957.

${ }^{50}$ SAB, NTS 1430 File No. 23/214, Volume I, Moteka to SNA, 17 June 1934.

${ }^{51}$ Ibid., Volume III, Moteka to SNA, 16 July 1945.

${ }^{52}$ SAB, NTS 1430 File No. 23/214, Volume I, Moteka to SNA, 17 June 1934.

${ }^{53}$ Ibid., Volume II, Moteka to SNA, 2 January 1942.

${ }^{54}$ Ibid., Volume III, Moteka to SNA, July(?) 1952.

${ }^{55}$ Ibid., Volume II, SNA to Ndhlovu, 25 September 1941.
} 
head of the church'. ${ }^{56}$ In 1956, the SNA informed Moteka that his church did not 'possess the standing and stability' necessary for the granting of official recognition. ${ }^{57}$

In the last years of his life, Moteka turned his letter-writing skills to different ends. He now used his letters to cement regional networks rather than to evoke membership within global Zion. Dispensing with the recognition procedure in the 1960s, the government's preference was now that the many Zionist organizations merge into a single body. ${ }^{58} \mathrm{~A}$ number of centralizing Zionist organizations emerged that aimed to unify smaller churches (Sundkler 1976: 292-3). Responding both to the change in government policy and to his own disillusionment with Zion, Illinois, Moteka turned his literary energies towards consolidating local Zionist groups by creating a federation of black ministers in the Bethlehem area. Moteka's final burst of letter-writing occurred in 1965, pleading, cajoling and exhorting his rivals to attend 'a meeting of all ministers and claimants to the headship of the church' in order to discuss amalgamation. ${ }^{59}$ He requested, in particular, that claimants bring with them 'someone who can read and understand letters and documents', underscoring his lifelong awareness of the legitimating power of paperwork, the promise of the written page to both make and break individuals' legitimacy within and beyond the borders of the nation state. ${ }^{60}$

But despite his later-life turn towards cementing local associations through print, Moteka still used letters to invoke the distinctive cosmopolitanism of Zionist piety. The tone of his final letter-written in 1965 when he proclaimed himself to be 'over 90 years old' 61 - is much the same as that of his over thirty years of letter-writing. Although Zion, USA may have failed him, he persisted in writing letters that invoked the promise of the 'Prince of Peace' to knit the world into a global fraternity. Moteka's final letter to the SNA encapsulates his multilayered movement between overlapping, frequently conflicting, loyalties. He was a small-scale black clergyman from the Orange Free State, uneasily located in the Republic of South Africa - a state that, although ambivalent about the inclusion of Africans within its borders, nonetheless insisted that they be subject to its authority. Straining against national borders, yet still unable to dispense with the recognition of local authorities, Moteka was also a worker in transnational Zion. And finally, he was a subject of 'the highest court of the universe', the Kingdom of God. His authorial voice embraces, without ever quite dissolving, the ambiguities of these various positions:

I am writing this letter in my capacity as Evangelist OFFICER-IN-CHARGE OF CCAC in Zion, in the whole Republic of South Africa. REV. I. S. MOTEKA under the HIGHEST COURT OF THE UNIVERSE. ${ }^{62}$

\footnotetext{
${ }^{56} \mathrm{Ibid}$., Volume III, SNA to Manager, NAD, Bloemfontein, 16 April 1951.

${ }^{57} \mathrm{SAB}, \mathrm{BAO} 7286$, Moteka to SNA, 28 January 1957.

${ }^{58}$ Ibid., BAD to Moteka, 11 July 1961.

${ }^{59}$ Ibid., Moteka to Ngema, 8 August 1961.

${ }^{60} \mathrm{Ibid}$., Moteka to Ngema, June 1965.

${ }^{61}$ Ibid.

${ }^{62}$ Ibid.
} 


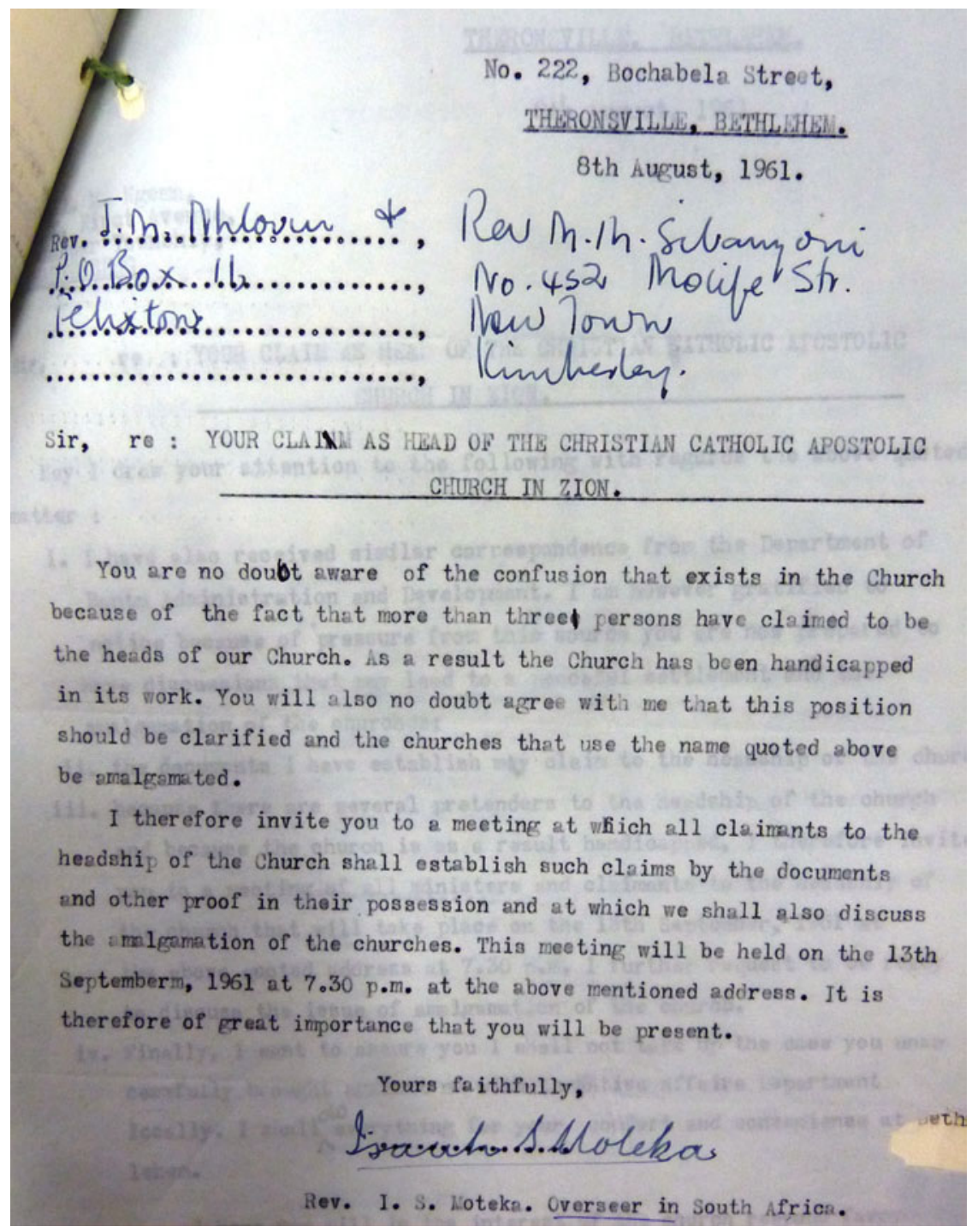

FIGURE 3 Typewritten letter to Moteka's rival claimants (reproduced with the permission of the National Archives and Record Service of South Africa)

\section{SUPPLEMENTARY MATERIALS}

Supplementary materials are available with this article at http://journals.cambridge.org/ action/displayCustomArticles?jid=AFR\&articleListId=1101. This is comprised of material from folders in NTS 1430 and BAO 7286 in the National Archives, Pretoria. These documents are reproduced with the kind permission of the National Archives and Record Service of South Africa. 


\section{REFERENCES}

Anderson, A. (1992) Bazalwane: African Pentecostals in South Africa. Pretoria: University of South African Press.

Barber, K. (2006) 'Introduction: hidden innovators in Africa' in K. Barber (ed.), Africa's Hidden Histories: everyday literacy and making the self. Bloomington IN: Indiana University Press.

(2007) The Anthropology of Texts, Persons and Publics: oral and written culture in Africa and beyond. Cambridge: Cambridge University Press.

Blumhofer, E. (1993) Restoring the Faith: the Assemblies of God, Pentecostalism and American culture. Urbana IL: University of Illinois Press.

Breckenridge, K. (2000) 'Love letters and amanuenses: beginning the cultural history of the working class private sphere in Southern Africa, 1900-1933', Journal of Southern African Studies 20 (2): 337-48.

Burns, C. (2006) 'The letters of Louise Mvemve' in K. Barber (ed.), Africa's Hidden Histories: everyday literacy and making the self. Bloomington IN: Indiana University Press.

Cabrita, J. (2014) Text and Authority in the South African Nazaretha Church. Cambridge: Cambridge University Press.

Campbell, J. (1998) Songs of Zion: the African Methodist Episcopal Church in the United States and South Africa. Oxford: Oxford University Press.

Claassen, J. S. (1995) 'Independents made dependents: African Independent Churches and government recognition', Journal of Theology for Southern Africa 91: 1-28.

Comaroff, J. (1985) Body of Power, Spirit of Resistance: the culture and history of a South African people. Chicago IL: University of Chicago Press.

Cook, P. (1996) Zion City, Illinois: twentieth-century Utopia. Syracuse NY: Syracuse University Press.

Fernandez, J. (1978) 'African religious movements', Annual Review of Anthropology 7: 195-234.

Hofmeyr, I. (2004) The Portable Bunyan: a transnational history of the Pilgrim's Progress. Princeton NJ: Princeton University Press.

_ (2013) Gandhi's Printing Press: experiments in slow reading. Cambridge MA: Harvard University Press.

Houghton, D. H. (1956) The Tomlinson Report: a summary of the findings and recommendations in the Tomlinson Commission Report. Johannesburg: South African Institute of Race Relations.

Khumalo, V. (2006) 'Ekukhanyeni letter-writers: a historical inquiry into epistolary network(s) and political imagination in KwaZulu-Natal, South Africa' in K. Barber (ed.), Africa's Hidden Histories: everyday literacy and making the self. Bloomington IN: Indiana University Press.

Kidd, C. (2006) The Forging of the Races: race and scripture in the Protestant Atlantic world, 1600-2000. Cambridge: Cambridge University Press.

Kiernan, J. (1978) 'Saltwater and ashes: some instruments of curing among some Zulu Zionists', Journal of Religion in Africa 9 (1): 27-32.

(1990) 'The canticles of Zion: song as word and action in Zulu Zionist discourse', Journal of Religion in Africa 20 (2): 188-204. 
(1991) 'Wear ' $n$ ' tear and repair: the colour coding of mystical mending in Zulu Zionist churches', Africa: Journal of the International African Institute 61 (1): 26-39.

Muller, R. (2011) African Pilgrimage: ritual travel in South Africa's Christianity of Zion. Farnham: Ashgate.

O'Brien, S. (1986) 'A transatlantic community of saints: the Great Awakening and the first Evangelical network, 1735-1755', The American Historical Review 91 (4): 811-32.

Oosthuizen, G. C. (1967) The Theology of a South African Messiah. Leiden: Brill. Opp, J. (2005) The Lord for the Body: religion, medicine and Protestant faith healing in Canada, 1880-1930. Montreal: McGill-Queen's University Press.

Peterson, D. and G. Macola (eds) (2009) Recasting the Past: history writing and political work in modern Africa. Athens $\mathrm{OH}$ : Ohio University Press.

Schoffeleers, M. (1991) 'Ritual healing and political acquiescence: the case of the Zionist churches in South Africa', Africa 60 (1): 1-25.

Sundkler, B. (1948) Bantu Prophets in South Africa. London: Lutterworth Press. (1976) Zulu Zion and Some Swazi Zionists. Oxford: Oxford University Press.

Vinson, R. (2012) The Americans are Coming! Dreams of African American liberation in segregationist South Africa. Athens OH: Ohio University Press.

\section{NEWSPAPERS AND GOVERNMENT PUBLICATIONS}

Leaves of Healing (Christ Community Church-formerly Christian Catholic Apostolic Church in Zion - Archives, Zion, Illinois).

The Comforter (Apostolic Faith Mission Archives, Johannesburg).

The Report of the Native Churches Commission for the Year 1922, Pretoria: Union Government, 1936.

\section{ABSTRACT}

South African Zionism, one of the most popular Christian movements in modern South Africa, has frequently been interpreted in narrowly indigenous terms, as a local, black appropriation of Christianity, heavily invested in orality and ritual performance. The correspondence of the twentieth-century Zionist minister Isaiah Moteka tells a different story. Moteka honed the craft of letter-writing in order to build and sustain his relationship with Zion, Illinois, the headquarters of the worldwide Zionist church. Through the exchange of letters across the Atlantic, Moteka affirmed his own and his congregants' place within a multiracial Zion diaspora. And through their complex invocation of overlapping local and global affiliations, Moteka's writings proclaimed his standing both as a regional clergyman and as a cosmopolitan internationalist. In particular, these ambiguous missives became the platform for Moteka's engagement with apartheid-era state officials. Seeking to persuade state officials that his organization fell under 'white' supervision, Moteka's letters proclaimed his accreditation by Zion, Illinois, thereby casting himself as a deputy of the worldwide movement. But these documents' citation of transatlantic loyalties also suggests Moteka's own conflicted loyalties. His letters asserted loyalty to the nation state while they simultaneously subordinated earthly power to the Kingdom of God. 


\section{RÉSUMÉ}

Le sionisme sud-africain, l'un des mouvements chrétiens les plus populaires de l'Afrique du Sud moderne, a fréquemment été interprété, dans des termes indigènes étroits, comme une appropriation noire locale de la chrétienté, fortement ancrée dans l'oralité et le rituel. La correspondance du pasteur sioniste Isaiah Moteka, au XX ${ }^{\text {ème }}$ siècle, relate une histoire différente. M. Moteka cultivait l'art épistolaire afin de développer et d'entretenir sa relation avec la ville de Zion, dans l'Illinois, siège international de l'église sioniste. Dans cet échange de lettres transatlantique, M. Moteka affirmait sa place, et celle des membres de sa congrégation, au sein d'une diaspora sioniste multiraciale. Et les écrits de M. Moteka, à travers leur invocation complexe d'affiliations locales et mondiales qui se recoupent, révélaient son rang en tant que pasteur régional et internationaliste cosmopolite. En particulier, ces missives ambiguës devinrent la plate-forme du dialogue engagé par M. Moteka avec les responsables de l'État sud-africain pendant l'apartheid. Cherchant à persuader les responsables de l'État que son organisation relevait d'une supervision «blanche », les lettres de M. Moteka proclamaient son accréditation par Zion (Illinois), se présentant par là-même comme un fondé de pouvoir du mouvement mondial. Mais la citation, dans ces documents, d'allégeances transatlantiques suggère également que M. Moteka avait des allégeances conflictuelles. Ses lettres affirmaient son allégeance à l'État nation tout en subordonnant simultanément la puissance terrestre au Royaume de Dieu. 


\section{THE LETTERS OF ISAIAH MOTEKA}

\section{LETTER 1}

House No. $222^{1}$

Native Location

Bethlehem, O.F.S. ${ }^{2}$

The Right Honourable

Secretary of the Native Affairs

Dept. Pretoria

4 June 1935

Dear Sir,

I received with thanks your good explanation according to the General Overseer of the Christian Catholic Apostolic Church (CCAC) in Zion: that the Reverend E.H. Mahon is the superintendent of the Christian Catholic Apostolic Church in Zion. I waited so long to give thanks for that explanation because I know well that the Rev E.H. Mahon is the superintendent of the Grace Missionary Church of America. I am sorry because the Rev E.H. Mahon of Mooigelegen ${ }^{3}$ deceived the natives of South Africa here so long as he said he is the superintendent of the above mentioned church. I am sorry because he is not ashamed even to deceive the Government. Rev E.H. Mahon has no right to use the Christian Catholic Apostolic Church in Zion when he rejected John Alexander Dowie, First Apostle in the Christian Catholic Apostolic Church in Zion. Whom after that God called him the First Apostle in the Christian Catholic Apostolic Church in Zion. The Christian Catholic Apostolic Church in Zion is the same as the Christian Catholic Church in Zion. Therefore E.H. Mahon got no right to use any part of the name of the Church the First Apostle restored because he rejected the First Apostle. But we do not want to hurt him. We want to show him very gently that he is a thief there in South Africa for using this Church without the authority of Edwin Harley Snelling of America. God may help him.

There is another thing I want to put in the office for the Native Affairs Department Pretoria. Which is this - there are some of the Native Ministers who have rejected the Rev E.H. Mahon. These ministers have bad teaching (hatred teaching). They teach the nations to hate the white people, when they began this teaching they did so to form their own church namely African Zion. But when they saw that people refused to follow them they went back again to the Christian Catholic Church in Zion but not under the Rev E.H. Mahon, because Mahon is a white man. Therefore we do not want anyone to use any part of this Church to spoil the Christian Catholic Apostolic Church in Zion. They can form their titles of hatred, but not Christian Catholic Apostolic Church in Zion.

\footnotetext{
${ }^{1}$ The following letter is from SAB, NTS 1430 File No. 23/214 Volumes I and IV.

${ }^{2}$ The Orange Free State (O.F.S.) was one of the four provinces of the Union of South Africa, declared in 1910. Bethlehem was one of its principal towns.

${ }^{3}$ This was the site of Mahon's mission station, south-east of Johannesburg in the Orange Free State.
} 
Because the teaching of the Christian Catholic Apostolic Church in Zion is Peace not Hatred, not division between white people and black people, hatred comes from the Devil, but peace from God. Therefore every tongue must speak God's praises and proclaim his Gospel throughout the world. White people and black people must first of all be united under the flag of our King George the Fifth and then become of the children of God. For it is written that there is no kingdom of this world which does not come down from heaven. I got the right to stop all those who want to spoil this church here in South Africa (I mean the CCAC in Zion) through the Power of the Acting Authority in the Christian Catholic Apostolic Church in Zion who is Edwin Harley Snelling under John Alexander First Apostle of the Lord Jesus the Christ.

No indeed, we do not let anyone use any part of the name of the Christian Catholic Apostolic Church in Zion.

God may bless our king George the Fifth. Amen. God may bless our prime minister in South Africa here amen. God may bless our Native Affairs Department, Pretoria. Amen. God may make peace between white people and black people. Amen.

Conclude: I have the honour to be my Lord, your obedient and humble servant,

Rev. Isaiah S. Moteka

\section{LETTER 2}

House No. $222^{4}$

Native Location

Bethlehem

To his Majesty's Principal

Magistrate Bethlehem District

26 July 1935

Honourable Sir,

If should receive grace in thy sight according to request which is: - on the $16^{\text {th }}$ July 1935 I was at office superintendent of Bethlehem Location, to seek for the rights of the Christian Catholic Apostolic Church in Zion, under John Alexander Dowie First Apostle of the Lord Jesus the Christ (in America).

But the Bethlehem Superintendent said this church is not known in the Government. Now my worship, I am surprised in that matter because this church is known throughout the world. But however, honourable Sir, this is how this church was organized: Dr Dowie came to Chicago in 1893. On February 221896 he organized the Christian Catholic Church in Zion. On September 241904 the

\footnotetext{
${ }^{4}$ The following letters are from SAB, NTS 1428 File No. 19/214-21/214.
} 
word (Apostolic) was inserted in the church name (Christian Catholic Church in Zion). And now my worship with honour and humility, let me say more please: in the Leaves of Healing, a weekly paper for the extension of the kingdom of God, edited by John Alexander Dowie, Volume XV No 11 Zion City Saturday July 2 1904 on the same year 1904. page 339, it says: 'The following named twenty seven believers were baptized in Johannesburg, Transvaal South Africa, Lord's Day 1904 by Overseer Daniel Bryant.'

Now my worship, this church may be known here in South Africa.

Peace to thee be multiplied my worship. God may bless thee in the office there. The power of the Almighty God be around thee day and night (amen).

God may help white people and black people be united under kind care hand or flag of the king George the Fifth amen.

I have the honour to be my Lord

Your most obedient and humble servant

Rev. Isaiah S Moteka

\section{LETTER 3}

House No. 222

Native Location Bethlehem

The Native Secretary Affairs Department Pretoria, South Africa

\section{January 1937}

Sir,

I have the honour and humility to write you this letter. I remember that on the $4^{\text {th }}$ Jun 1935 I wrote to you that there is no man we can allow to use the name of the Christian Catholic Church in Zion in Africa. If there is a man who claims to be recorded in Government with this church, Christian Catholic Church in Zion, without John Alexander First Apostle of the Lord Jesus Christ. Edwin Harley Snelling acting authority in CCAC in Zion under First Apostle. I am in that way asking for advice from you as a leader of the Native Affairs. If anyone who uses that title like Rev. E.H. Mahon whom you said he was the only one using it. I thought it a mistake because he belongs to the Grace Missionary Church, that I can prove to him if you would know about the matter. I shall be glad to hear that he is no longer using that title because even now he still belongs to the Grace Missionary Church. Dear Sir as I am representative man, and a secretary of the Conference of the Triumverate Council of Investigation in SA in CCAC in Zion under John Alexander First Apostles, Edwin Harley Snelling Acting Authority. My will is just that the white and black nation should understand one another and work in Peace under the kind care of our king in 
England where our palace of hope is, so that God can promote our kingdom of England (Amen).

Examine the seal above, and find my standing, and oblige, kindly reply.

Yours sincerely

Rev. Isaiah S. Moteka

\section{LETTER 4}

Ecclesiastical Executive Council ${ }^{5}$

In the Christian Catholic Apostolic Church in Zion 2815 Ezra Avenue Zion City, Ill., USA

Native Affairs Department

Pretoria, Transvaal

South Africa

25 May 1940

Honourable Sirs,

Peace to thee:

This is to certify that the Rev Isaiah S Moteka of House No 222, Native Location, Bethlehem, O.F.S. South Africa, has been appointed Deputy Overseer and Official Representative of the work in South Africa for the Christian Catholic Apostolic Church in Zion, under our hand.

Very respectfully yours,

Edwin Harley Snelling

Acting Authority

\section{LETTER 5}

House No. 222

Native Location

Bethlehem

The Secretary

Native Affairs Dept.

Pretoria

8 July 1940

Greetings Sir,

I am writing to you on the case of a great number of Ministers who call themselves by false means to be the Christian Catholic Apostolic Church in Zion, as their right religion or denomination. These kind of ministers are constantly

\footnotetext{
${ }^{5}$ The following letters are from SAB, NTS 1430 File No. 23/214 Volume II.
} 
asking the Government to offer them full rights of conducting this religion while they have not passed and known the Government's regulations for the offer of such rights.

Therefore honourable I undertake the opportunity of asking the Government to rely on me for such cases as I am the only right Deputy Overseer of this Church in SA, as being given the rights by the Executive Ecclesiastical Executive Council in America of this Church in America.

I am therefore the only Deputy Overseer who has the right to consult the Government on such matters, when the time is ripe for it to receive full consideration by the Government.

I am sir

Your obedient Servant

Isaiah Moteka

LETTER 6

House No. 222

Native Location

Bethlehem

\section{January 1942}

Dear Sir,

I have the honour to let the honourable gentleman understand that although I am keeping silence, I am not silent. I am still running after the above church and after all I am thanking the Master for the great help in the same period. I still lay myself before the Master though the Troubles of my Nation which can't build them up or can't build a good thing up, for them. My Lord it's really very far for us to have a good civilization. We can be educated, but it's in vain.

As the Master heard me speaking like this, it's because I see that we can't build up this Christian Catholic Apostolic Church in Zion. All these Zulus trying to be the enemies of this church. Why? Because one wants to be bigger than the others. J.B. Ndhlovu is fighting against IS Moteka because he was surprised to be the first, but he failed to carry on with the church. As I understand, he couldn't send overseas to get the good support for him. As we wished to wake up and carry on with the work here. He is in our way. I did join up with him but after I heard from my advisor I stopped working together with him. Now, Sir, after all, that's why I am saying your help is very good to us. I must thank the Master and hoping the same Authority to give us a hand and stop these in using the name of ours in trading money amongst Natives.

PS Sir, I am also appointed to hold up this church in Transvaal and outside Transvaal and I hope the Master will soon get a letter.

From Rev. I.S. Moteka as he is the Head of the said church. 


\section{LETTER 7}

House No. 222

Native Location

Bethlehem

To the Secretary

Native Affairs Dept.

Pretoria

23 April 1942

Sir,

I thank you sir for your letter of the $14^{\text {th }}$ April 1942. May God bless you, until Jesus Christ comes.

Please my worship be kind to receive my request which I should like to bring before you. In your letter of the 10 Jan 1942, when you wrote to me instead of 'I' you did write ' $\mathrm{J}$ '.

Again, in your letter of the $14^{\text {th }}$ April 1942, instead of Moteka you put Moeteka. Therefore with honour and humility, I should like you, please sir, to write my name always in a proper way, please.

May God bless you and guide you there in your office. Amen.

I have the honour to be sir,

Your obedient (Sir)

(your) servant

Isaiah S Moteka

Under the kind Banner of our noble King of England. Amen.

\section{LETTER 8}

\section{May 1942}

The Christian Catholic Apostolic Church in Zion

Sir, the above church with Headquarters in Bethlehem O.F.S. has numerous branches throughout the Union; as well as outside the Union as a result of the fast growing and developing of this church, we humbly beg that it should be recognized by the Government.

We further request that treatment meted out to the Members of this Church by the Police should be less serious and moderate.

Thanking you in anticipation

We have the honour to be Sir

Your humbly servants

Signed Elder IS Moteka No 222 Bethlehem O.F.S. 


\section{LETTER 9}

Christian Catholic Apostolic Church in Zion

No 222

Location Bethlehem, O.F.S.

The Secretary

Native Affairs Department

Pretoria

7 July 1942

Sir,

As a deputy overseer for SA in the work of the Christian Catholic Apostolic Church in Zion, under John Alexander First Apostle, Edwin Harley Snelling, acting Authority, I beg to apply for the Government Recognition of the abovenamed church by the South African Government.

It was founded by John Alexander in Chicago, Illinois, USA, on February 22 ${ }^{\text {nd }}$, 1896. I was appointed to the position of Deputy Overseer for SA on the $27^{\text {th }}$ Day of July 1938 by Edwin Harley Snelling of 2815 Ezra Avenue, Zion City, Illinois, USA.

I am holding the preachers' certificate in the Christian Catholic Apostolic Church in Zion, in the Union of South Africa, Basutoland and Swaziland. This church has 879 members in the Union of South Africa, Basutoland and Swaziland.

Hoping my application will meet with your favourableconsideration.

Your obedient servant,

Rev. Isaiah S Moteka

LETTER 10

South African Police 6

Office of the District Commandant

Bethlehem

The Magistrate

Bethlehem

8 March 1943

Application for Government Recognition: Christian Catholic Church of Zion

I have the honour to report for your information as under:

1) This church was established in this district in 1934

2) The church in question does not own any fixed property

3) There are no schools under the management of this church, and are not in receipt of any government grants.

${ }^{6}$ The following letters are from SAB, NTS 1430 File No. 23/214 Volume III. 
4) The total membership are-Bethlehem 36, Paul Roux, 7 and Kestell 12.

5) The Rev. Isaiah S. Moteka is the head overseer of this Church in South Africa. The Christian Catholic Church of Zion originates from America where it was first established by the late John Alexander in 1896. There is nothing detrimental known against the character of Isaiah S. Moteka, who is well known in Bethlehem.

6) Very little is known of the teachings of this church, but as far as can be ascertained it is not conducive to the observance of Law and Order. It, however, does not seem to carry favour with the Bantu people.

There are no European congregations of this church in the Union.

Sgd. D. Coetzee

Inspector

District Commandant, S.A. Police

No. 28 District, Bethlehem, O.F.S.

\section{LETTER 11}

Stand No. 222

Bethlehem Location

The Secretary

Native Affairs Department

Pretoria, South Africa

\section{July 1943}

For the Church of God. Hebrews 12:21-22. ${ }^{7}$ I will hold up my hands to Heaven until my God, including Native Affairs Department Pretoria, prevail against the power of the Devil, and bring back all nations to God. Romans 13: 1 to $7 .{ }^{8}$ May God help us to obey any higher powers in this world. Then I will be a fine minister of God. Let us all be one under the domain of the King of England and until the coming of the Lord Jesus Christ, for it is that when the time of the Lord Jesus is at hand and nations of the world should be one nation and praise the Lord Jesus in unity through faith come down the Right Almighty God. Hallelujah, Amen, the Lord is coming again.

Ha! What is written in the Holy Bible of God: Revelation 18:18. ${ }^{9}$ Who is that man 666? We all know who is he, through the Holy Spirit of God. Let every nation extol the name of the Most High. God is coming very soon, lift up the Banner of

\footnotetext{
7"And so terrible was the sight, that Moses said, "I am full of fear and trembling." But you have come to Mount Zion and to the city of the living God, the heavenly Jerusalem, and to myriads of angels.' Hebrews 12:21-20 (New American Standard Bible).

${ }^{8}$ 'Every person is to be in subjection to the governing authorities. For there is no authority except from God, and from those which exist are established by God. Therefore whoever resists authority has opposed the ordinance of God; and they who have opposed will receive condemnation upon themselves.' Romans 13:1-2 (New American Standard Bible).

9، And every shipmaster and every passenger and sailor, and as many as make their living by the sea, stood at a distance, and were crying out as they saw the smoke of her burning, saying "What city is like the great city?"' Revelations 18:17-18 (New American Standard Bible).
} 
England, the place of our hope. God may bless our native affairs department, Pretoria, until Jesus Christ comes, Amen.

I am the servant of the servants of God, under the kind care of the King's Banner (England).

Rev. Isaiah S. Moteka

\section{LETTER 12}

No 222 Location

Bethlehem

O.F.S.

The Secretary for Native Affairs,

Pretoria

12 April 1945

Dear Sir

In my letter dated the $1^{\text {st }}$ Jan 1942 , I had requested you to register my church viz. 'The Christian Catholic Apostolic Church in Zion. You acknowledged receipt of this letter on the $10^{\text {th }}$ June 1942.

It is strange to find out that up to date this church has not registered.

I hereby request you to register it and publish it in all towns in the Union of South Africa and Basutoland.

I always encounter much difficulty when I have to serve Holy Communion. The Magistrate refuses to give me permission for purchasing wine.

Kindly grant me full permission of purchasing wine for Holy Communion wherever I may have to serve some to my communicants. The favour of an early favourable reply will much oblige.

Yours faithfully

Isaiah S. Moteka

\section{LETTER 13}

Stand No. 222

Location

The Secretary for Native Affairs

Bethlehem, O.F.S.

16 July 1945

No 1 - Qualifications: I have passed Standard 4, Paris, Evangelist, Missionaries at Cana School Basutoland under D Jeanmaint (12. 1912). I studied ministry through correspondence for five years, taught by Edwin Hardy Snelling acting authority 2815 Ezra Ave, Zion City Illinois, USA. I am now of the intention to study English through correspondence. My ministers have learned only their 
respective mother tongues, except in the case of John Kakundhi who has passed Standard 4 at Colony and Charles Matholo Standard 3 Phoku Basutoland, and Reuben Marumo Afrikaans, and Dlomo Standard 6, Colony (at present Germiston)

No 2 - The Christian Catholic Apostolic Church (hereafter CCAC) in Zion was organized in 1896, re-established in 1906 by John Alexander First Apostle in America.

No 3 - The Christian Catholic Apostolic Church in Zion is the foundation of all the Zion and Apostolic churches. It was established in this manner there. He was a man sent from God whose name was John Alexander Dowie First Apostle of the Lord Jesus Christ in CCAC in Zion. He was born in Edinburgh, Scotland, May 25,1847 . Very early in life he responded to God's call to the ministry. He organized the Divine Healing Association throughout the world, of which he was president and which he disbanded previous to the organization of the CCAC in Zion on February $22^{\text {nd }} 1896$. Which became a mighty power under his direction as General Overseer where he continued to labour until his passing away from his earthly toils and of his triumphant entry into the Zion above, March 9 1907. Lake Mount Cemetery holds the sacred dust of our beloved. God may help me to stand to the right. Amen.

No 4 - With the management and selection of ministers, at present, I first discern the ability of a man before he is considered. He is put under test for three years. In the first year, he is tried by the conference. In the second, he appointed under the supervision of a qualified minister. Having been found competent, he is given ministry of a church in his third year. It is a scheme that in future the church will establish a Bible school to train ministers when the school has been recognized by the Government. But I hope that the Government school of Bible is the best for the training of ministers, since its method of training for ministers by teaching Bible and not special management by a certain church, can be best to create understanding among various churches. Various churches in the methods of training ministers only deal with those elements that are necessary to individual church over the world. Thus speaking against one another, each claiming its doctrine is the genuine one. But if ministers are trained in scriptures they can do no ill speaking against each other. The difference can only be in the ability of the God-given. The fact that teachers today judge no difference amongst them makes it clear that in O.F.S. there is understanding.

No 5 - The church services are at present conducted in private stands. The reason is that the church is not yet registered and recognized by the Government.

No 6 - The church total of membership

O.F.S. -334

Cape Colony -267

Transvaal -40

Total -640 members

No 7 -The fund of the CCAC in Zion is banked the purpose is to establish schools and church buildings and to maintain the ministers. But most important in purpose is to aid the Government by giving the tithes to God. 
No 8 - Just as I have explained the organization of this church in No $3 \mathrm{I} \mathrm{am}$ supervised by European ministers who are in America. The Government has seen my minister's certificate issued from America. I hereby send my certificate for examination by the Government. This will make clear that I am being supervised by European ministers. In the case of facilities to obtain wine, I have been duly furnished by my magistrate at Bethlehem with a grant.

\section{My request - please my worship}

Concerning the government recognition of the CCAC in Zion I wish the government to give me an allowance of few years. I am however applying for registration of CCAC in Zion in the list of legalized churches in all the government offices of all towns to enable me to abolish the preaching of these churches who carry sticks and rope around them and get claiming to work through the CCAC in Zion. But sometimes accidents occur at their preaching places through fights which arise. Sometime ago I asked the magistrate to take certificates away from such men. The magistrate replied that he was unable because the CCAC in Zion was not in the list of registered churches. He advised me to apply for Registration to Government - so that they would help me to stop them.

This is my request. Please my worship.

Yours obedient servant,

(Rev.) Isaiah S. Moteka

The Rev. Isaiah S. Moteka

\section{LETTER 14}

The Christian Catholic Apostolic Church in Zion

Stand No. 222

Bethlehem Location

Bethlehem

\section{August 1945}

\section{Dear Sir}

I have to acknowledge receipt of your letter $16^{\text {th }}$ ultimo. It is regretted however that your church has not yet reached that stage of development which would justify the Department in recommending the grant of Government recognition. It is observed that the church possesses no buildings and the total membership of all congregations is only 640. The educational qualifications of your ministers also falls short of the required standard and no proper provision appears to have been made for the training of these ministers. These factors militate against the grant of government recognition. There are however no objections to the holding of bona fide prayer meetings provided the requirements of law and order are observed.

Secretary for Native Affairs 
LETTER 15

Stand No. 222

Location

Bethlehem, O.F.S.

Secretary

Native Affairs Department

Pretoria

12 January 1949

Dear Sir,

I learn Government this letter which is called General letter from America written on the $30^{\text {th }}$ July 1934. This man known as JS Maduna and his assistants were instructed by America to work as this letter tells, but Maduna failed. Then America elected me in his place as the Government has seen my appointment for some past time from America. The cause why these ministers fail in this church Christian Catholic Apostolic Church in Zion is that they have the Spirit of Segregation between the nations, especially referring to the whites. However, Zion hit them hollow. Why?

Because Zion is the Kingdom of God, we ought to meet there all, not with flesh but spiritually with the spirit from God. My desire is to fulfil the Government's law together with God's. Romans 13. I beg the Government to help me by speaking with the Municipal of Bethlehem, that as the removal of our Location Bethlehem is not actually known the municipal should obediently allow me to put roofs as the walls are long finished, except two rooms at the back which we did not build because of the municipal. So that I should work in this church as the Government has commanded in the letter of 30 April 1945, No 577/214. And years which Government's law has given me to put this church in its right form. I have noticed that these years will pass before the HQ office of this church stands on its two feet.

But not that I have no strength. I hate to be disobedient to the Government's law. I want the Government to trust me as ministers are the assistants of the Government, to teach and lead the nation to the right. I ask this - that the Government should help me, that municipal should give me an allowance to put roofs on this house, as I have no place to hold the church's services, to teach my ministers as the Government's law says that churches must teach their ministers to hold God's services. I ask the Government to examine this building, and to see as whether it fits to be the HQ, as the whole of South Africa is governed from Bethlehem in this church.

I will wait patiently and obediently for the same mercy from the Government together with the municipal of Bethlehem.

Yours obediently servant, Rev. Isaiah S Moteka. 
LETTER 16

Stand No 222

Location

Bethlehem

Bart M Wilkinson

2435 Emmaus Avenue

Zion, Illinois

24 July 1952

Dear Sir,

Peace in the name of Zion. Your letter has been received with pleasure. I debated to reply just because we have been praying for you so that we may understand with each other well as it was the case with the late Snelling.

I should like to bring this to your attention: I have in been in this Church of Zion for the last 47 years. I joined the church in 1905 in the days of First Apostle (John Alexander). I am now 67 years of age. All the members of the church left Zion in 1905. I am left alone, but God has been with me. I have congregations in Free State, Basutoland, Transvaal, Cape Province and Swaziland. It is quite clear when you say that the stamp I am using is to be changed as Snelling has passed away, but this must first be reported to the Government of South Africa. It must clearly be stated that you are the person who has taken the place of the late Snelling. I hope God will help you carry on the work in harmony. I am quite willing to remain obedient under your service.

The Ministers of South Africa are under John Alexander First Apostle. They are known to the Government of this country by the certificates I am enclosing herewith now.

The appointment enclosing herein was sent by the late Rev Snelling and also from the Government. By the help of our God I hope our work will be run very smoothly by working together in peace and harmony as it has been the case in the days of the late Snelling acting Authority.

With wishes, Yours in Christ,

(for) Rev. Isaiah S. Moteka,

Deputy Overseer Chief Triumvir in Christian Catholic Apostolic Church in Zion Throughout SA (stamp) 
LETTER 17

Stand No 222

Location

Bethlehem

Secretary

Native Affairs Department

Pretoria

22 September 1952

Dear Sir

I humbly notify you my worship that I hold conference in Bloemfontein Location on the $18^{\text {th }}$ August 1951. I had invited all congregations called the Apostolic Church in Zion. The Full Gospel Church Building was filled to capacity. My aim was to bring about unity so that all these sects may become one church.

I was greatly disappointed to be denied the right to purchase sacramental wine by the Magistrate of Bloemfontein who told me my church was unrecognized by the Government. He advised me to interview the Native Commissioner who also said I should take the Magistrate's word. It is strange because on the $4^{\text {th }}$ November 1950 the same Magistrate gave me permission to buy wine. I was obliged to use ginger beer mixed with a juice from raisins.

I humbly request you to communicate with this Magistrate to allow me to purchase wine because I was recognized by Government as a minister of religion on the $26^{\text {th }}$ May 1942. I have been a Christian of good character for 48 years. I am a man of 66 years of age. I am enclosing herein letters giving good reasons why my church is not recognized in South Africa.

I am also enclosing letters which I use here in Bethlehem for obtaining wine. I never had trouble out here about purchasing sacramental wine. In the letters from America it will be noted that the Christian Catholic Apostolic Church in Zion is inconvenienced by the Apostolic Faith Mission and Mahon Mission to get recognition. It is an old church.

Since my church is registered, I am entitled to serve Holy Communion among followers.

I was welcomed by the Location Superintendent of Bloemfontein.

I beg to remain, My Worship, your faithfully servant, Rev. Isaiah S. Moteka (stamp) 
LETTER 18

The Christian Catholic Apostolic Church in Zion ${ }^{10}$

No 222 Bochabelo Street

Bethlehem

The Secretary

Native Affairs Department

Pretoria

9 March 1957

Sir,

I here wish to thank you very much for your letter of the $8 / 3 / 57$ being answer to my enquiry.

I understand from your letter that you say that there are six people who claim to be the heads of my church. To my knowledge, Sir, I know of nobody here in South Africa who may claim my church. I can only expect such claims from people in America.

If you could check up your files of 1940 (I'm unfortunately not sure of the date) between the months of January and June, you will definitely find a letter written to your office by Rev. Edwin Harley Snelling of America wherein he says that I am the sole appointed head of the Christian Catholic Apostolic Church in Zion here in South Africa.

I humbly ask you to be patient with me on this matter and let me know who these people are, whether here locally or in America.

Hoping to hear from you soon,

I wish to remain

Yours in Christ,

Isaiah S. Moteka

'Peace be still between white and black, says the Prince of Peace to the Prince of Darkness'

[Isaiah's stamp at bottom]

${ }^{10}$ The remaining letters are from SAB, BAO 7286. 
LETTER 19

222 Bochabelo Street

Thereneville,

Bethlehem,

Orange Free State,

South Africa

[Isaiah’s stamp]

Triumverate Council of Investigation

Christian Catholic Apostolic Church in Zion

South Africa under Rev. Isaiah Moteka Deputy Overseer

Mr Vernon R. Lee

Mr Bart M. Wilkinson

Presiding Officers.

25 July 1957

Peace be with you all you Zionists.

I received your letter in 1955 just when I had arrived from Natal from dedicating a new church building.

I was at the time seriously ill suffering from eyesight. Up to this day I am unable to read or write. In your letter you asked me to let you know of any impediments that interfere with the progress of the church. I must say that there are no troubles at all with me out here in South Africa even from my Government, since Lettie H. Snelling introduced me to the Government in Pretoria.

People who are spoiling things out here are Americans. You have taken a different administration from that of Snelling. I introduced all the ministers here to Snelling but under you there are now ministers here in South Africa who I don't know, whose characters you also do not know and yet you have awarded them certificates that they are Bishops. I refer particularly to Mr. Nyaweni who is known to you out in the Transvaal. He says he was placed by you as Bishop and will simply not pull together with us. I would ask you if you are really occupying the seat of Snelling under John Alexander First Apostle.

I have a complete roll of all the ministers here in South Africa compiled by Lettie Snelling and the name of Mr Nyaweni is not there. I would like you to tell me where you got his name. People like him have spoiled things here in South Africa. They say they are under the control of the Holy Ghost even when they have their legal wives they desert them and just remarry. Saying it is the instruction of the Holy Ghost. I don't like such misunderstandings in our church. I don't claim to have people those people of whom I am the leader in the CCCAC in Zion are God's people. Read Romans Chapter 13. 
What I preach is this: Let there be peace between white and black. So says the Prince of Peace to the Prince of Darkness.

Your friend in Christ,

Isaiah Moteka

(Chief Triumvia in C.C.A.C. in Zion)

The Triumverate of Investiation

Christian Apostolic Church in Zion under Isaia Moteka

Deputy overseer and chief triumvia

Head quarter 822 Location Bethlehem

\section{LETTER 20}

222 Bochabelo Street

Bethlehem Location

O.F.S.

South Africa

Rev Vernon R. Lee

2721 Elizabeth Avenue

Zion, Illinois

10 July 1958

\section{Dear Sir}

Peace be with you together with our mother Mary Snelling and to all friends in Zion. I have received your letter in which you informed me that you have taken the place of your grandfather Snelling and that he has passed away having something to say to me. I am anxious to know what he wanted to say to me about the mission work in South Africa. Please let me know what he was anxious to tell me about the mission work. All I know is that he wanted the white people and black people of South Africa to live in peace. I am trying my best to live peaceably with all the ministers of religion under me and also to live in harmony with white and black people of South Africa.

I conclude by saying 'peace be still between white and black. Says the prince of peace to the prince of darkness. I hope you will reply before Christmas.

Your humble servant,

Rev. Isaiah Moteka.

\section{LETTER 21}

[No address or date]

\section{Dear Francis}

I am in receipt of your letter of 1 June 1965 and I pleased to learn of your conference to be held in Johannesburg. 
I wish to say that when you arrive at the Conference, please don't give the church money to anyone. This is my ruling order. If Mr Ngema is not happy with the setup he is at liberty to report me or appeal to anyone as protest. I am prepared for the challenge.

So please do not hand over money before Mr Ngema and I have conferred.

Therefore may I ask you that when you come please bring someone who can read and understand letters and documents here to me so that you should know where and what your church registration number is in Pretoria. This should help this matter now being approved. I wish to thank God for you as the one under me for your efforts and please catch hold of Mr Ngema because for a long time he has been elusive and not responding to invitations.

I am writing this letter in my capacity as Evangelist OFFICER - IN - CHARGE OF CCAZ in Zion, in the whole Republic of South Africa. REV IS MOTEKA under the HIGHEST COURT OF THE UNIVERSE No 1-2

I should be pleased if you could read this letter to the conference because it is not private and confidential. Please convey to Mr Ngema to read Act of the Apostles Chapter 5: 11-14.

I am today over 90 years old.

Thanks God.

Isaiah Moteka 